\title{
HUBUNGAN PELVIC CROSS SYNDROME DENGAN KELUHAN LOW BACK PAIN PADA MAHASISWA PROGRAM STUDI FISIOTERAPI DAN PROFESI FISIOTERAPI FAKULTAS KEDOKTERAN UNIVERSITAS UDAYANA
}

\author{
I Putu Yudi Pramana Putra ${ }^{1}$, M. Widnyana ${ }^{2}$, Ni Luh Gita Karunia \\ Saraswati $^{3}$,A.A Gede Eka Septian Utama ${ }^{4}$ \\ ${ }^{1,2,3}$ Departemen Fisioterapi Fakultas Kedokteran Universitas Udayana, Denpasar \\ Bali \\ E-Mail : yudipramanaputraa@gmail.com
}

\begin{abstract}
ABSTRAK
Pendahuluan: Pelvic cross syndrome merupakan suatu gangguan keterbatasan musculoskeletal kompleks di mana terjadi imbalance dengan pola yang spesifik antara muscles tightness (illiopsoas dan spinal ekstensor) serta muscles weakness (abdominal dan gluteus) dengan pola menyilang (Cross pattern) antara sisi pelvic bagian anterior dan posterior dari tubuh manusia. Adanya koreksi dan assessment dini dari malalignment yang terjadi merupakan upaya preventif perubahan postur pelvic akibat imbalance muscles di mana secara biomekanika akan memberikan kompensasi pembebanan pada otot- otot di sekitar. Tujuan Untuk mengetahui hubungan pelvic cross syndrome dengan pada mahasiswa program studi Fisioterapi Fakultas Kedokteran Universitas Udayana. Metode: Jenis penelitian ini adalah studi prevalensi dengan menggunakan rancangan cross sectional survey. Subyek penelitian ini adalah mahasiswa laki- laki dan perempuan Program Studi Fisioterapi dan Profesi Fisioterapi Fakultas Kedokteran Universitas Udayana sebanyak 200 orang dengan menggunakan teknik pengambilan sampel secara consecutive sampling. Adapun pengukuran dari postur pelvic diukur dengan mengukur kekuatan dari abdominal muscle dan gluteal muscle dengan Manual Muscle Technique dan pengukuran dari tightness dari hip flexor dengan Thomas Test dan pengukuran fungsional pinggang dengan kuesioner ODI (Oswestry Disability Index). Hasil: SPSS versi 23 telah digunakan untuk melakukan analisis data di mana didapatkan hasil $21 \%$ dari total populasi memiliki pelvic cross syndrome pernah memiliki keluhan Low Back Pain. Didapatkan juga hasil pengukuran pelvic cross syndrome dengan sample berjenis kelamin perempuan adalah 83 orang dari total 120 sample $(69,16 \%)$ lebih banyak mengalami pelvic cross syndrome dibandingkan laki-laki yaitu 14 orang dari 80 sample $(18,75 \%)$. Simpulan: Prevalensi kejadian pelvic cross syndrome pada subjek perempuan lebih tinggi dibandingkan laki-laki pada kelompok usia yang sama (18- 22 tahun). Saran: Untuk peneliti selanjutnya dapat dilakukan follow up research untuk melihat hasil jangka panjang efek dari Pelvic Cross Syndrome pada mahasiswa laki- laki dan perempuan Program Studi Fisioterapi dan Profesi Fisioterapi Fakultas Kedokteran Universitas Udayana
\end{abstract}


Kata Kunci; Pelvic Cross Syndrome, Low Back Pain, Manual Muscle Technique, Thomas Test, Oswestry Disability Index

\title{
THE RELATIONSHIP OF PELVIC CROSS SYNDROME WITH LOW BACK PAIN PROBLEM STUDENT OF PHYSIOTHERAPY STUDY PROGRAMS AND PHYSIOTHERAPY PROFESSION OF MEDICINE FACULTY, UDAYANA UNIVERSITY
}

\begin{abstract}
Background: Pelvic cross syndrome is a complex musculoskeletal disruption which occurs specific patterns imbalance between muscles tightness (illiopsoas and spinal extensors) and muscles weakness (abdominal and gluteus) with cross patterns (cross patterns) between the anterior and posterior pelvic sides of the human body . Correction and early assessment of malalignment is an effort to prevent changes in bad pelvic posture due to imbalance muscles where from biomechanical perspective will compensate on the surrounding muscles. Purpose: To determine the relationship of pelvic cross syndrome on Physiotherapy study program students at the Faculty of Medicine, Udayana University. Methods: This research is prevalention research with used rancangan cross sectional survey design. Subject of this research are student man and woman Program Study Physiotherapy and Profession Physiotherapy of Medical Faculty Udayana University with 200 sample with using taking sample technique consecutive sampling. For measurement of posture pelvic was using with measure strengthening of dari abdominal muscle and gluteal muscle with Manual Muscle Technique and measurement of tightness dari hip flexor dengan Thomas Test and measure of fungtional back with ODI (Oswestry Disability Index). Result : SPSS version 23 already used for analysis the data where get the result $21 \%$ from all over population have pelvic cross syndrome and have low back pain. At this researches get also measurement pelvic cross syndrome on woman is 83 subject from all 120 sample $(69,16 \%)$ more pelvic cross syndrome on man is 14 people from all over 80 sample $(18,75 \%)$. Conclusion : Pelvic cross syndrome on subject woman is higher than on man in the same age group (18-22 years old). Suggestion : For the next researcher can do follow up research to see long-term result of Pelvic Cross Syndrome on woman and man student of Physiotherapy study program students at the Faculty of Medicine, Udayana University
\end{abstract}

Key word; Pelvic Cross Syndrome, Low Back Pain, Manual Muscle Technique, Thomas Test, Oswestry Disability Index 


\section{PENDAHULUAN}

Postur merupakan suatu gambaran bentuk dari anatomi tubuh manusia dalam merespon suatu gaya eksternal. Postur yang ergonomis dapat menurunkan tension dari otot yang bekerja dan meminimalisir adanya kompensasi tambahan pada otot lain. Otot sebagai mekanika yang berperan dalam mempertahankan postur berperan penting agar tercipta postur tubuh yang baik ${ }^{1}$

Otot sebagai mobilisator utama tubuh manusia secara esensial dapat dibagi menjadi dua sistem yaitu; deep muscle dan superficial systemic muscle sistem. Deep muscle berperan penting dalam support dari postural control dan memberikan support yang lebih dalam menjaga stabilitas sehingga juga dapat menjadi functional bridge system antara lower torso dan leg pada saat melakukan suatu gerakan ${ }^{2}$.

Pada era global di mana semakin tingginya tekanan stress pada tubuh berbagai keluhan mulai ditemukan muncul dan nyeri pinggang atau yang biasa kita kenal dengan low back pain (LBP) merupakan urutan ke dua penyebab penurunan dari kualitas aktivitas fungsional yang hampir setiap orang pernah mengalaminya daripada keluhan lain ${ }^{2,3}$.

Keluhan pasien LBP itu sendiri juga menjadi alasan yang sering dan yang paling umum dikeluhkan saat datang ke praktek fisioterapi. Keluhan low back pain ini sendiri menurut hasil survey yang dilakukan oleh Justyna et al. pada tahun 2015 menempati urutan $5^{\text {th }}$ untuk seringnya dirawat inap di rumah sakit dan urutan ke $3^{\text {rd }}$ sebagai alasan dilakukannya prosedur operasi. Satu individu di antara $70 \%$ dan $80 \%$ populasi di dunia pernah merasakan keluhan LBP selama hidup mereka yang dapat berlangsung dalam hitungan hari, bulan dan tahun $^{4}$. Banyak dari pasien LBP melaporkan keluhan hilang dalam satu waktu dan kembali dikeluhkan setelahnya, sehingga banyak peneliti mencari sumber dari patologi LBP itu sendiri. Konsep imbalance muscle menjadi jawaban atas keluhan LBP chronic yang terus dirasakan ${ }^{5,6}$.

Diharapkan dengan screening awal pada sampel akan terjadi perubahan postur sejak dini terutama pada lower back dan pelvic sehingga dapat meminimalisir adanya keluhan ke depannya. Selain itu calon fisioterapis di masa depan harus mempunya postur yang tegap guna mengantisipasi pasien diluardugaan seperti pasien dengan IMT tinggi ataupun saat intervensi pasien dengan kondisi posisi yang buruk.

\section{METODE PENELITIAN}

\section{A. Rancangan Penelitian}

Desain pada penelitian yang telah dilakukan di sini adalah cross sectional study dengan tujuan menemukan gambaran prevalensi kejadian dari pelvic cross syndrome pada mahasiswa laki-laki dan perempuan Program Studi Fisioterapi Fakultas Kedokteran Universitas Udayana.

\section{B. Tempat dan Waktu Penelitian}

Penelitian dilakukan pada di gedung Fisioterapi pada 200 orang mahasiswa dan mahasiswi Program Studi Fisioterapi dan Profesi Fisioterapi Fakultas Kedokteran Unuversitas Udayana angkatan 2017, 2018 dan 2019 antara bulan Agustus sampai September 2019. 


\section{Populasi dan Sampel}

Seluruh mahasiswa dan mahasiswi Program Studi Fisioterapi dan Profesi Fisioterapi Fakultas Kedokteran Universitas Udayana adalah populasi target pada penelitian ini. Sedangkan pada populasi terjangkau dalam penelitian ini adalah seluruh mahasiswa laki-laki dan perempuan yang terindikasi mempunyai postur pelvic cross syndrome dan telah memenuhi kriteria inklusi serta eksklusi masuk sebagai sampel di penelitian ini.

\section{Teknik Pengambilan Sampel}

Teknik pengambilan sampel accidental dan consecutive sampling merupakan teknik pengambilan sampel dalam penelitian ini. Sebelum menjadi subjek penelitian terlebih dahulu telah mengisi informed consent sebagai persetujuan menjadi sample penelitian.

\section{E. Prosedur Penelitian}

Prosedur penelitian ini adalah:

Tahap persiapan dan Tahap Pelaksanaan.

Tahap Persiapan : (a) Meminta ijin kepada Program Studi Fisioterapi dan Profesi Fisioterapi Fakultas Kedokteran Universitas Udayana sebagai tempat melakukan penelitian; (b) Peneliti membuat surat ijin penelitian dan ditandatangani Ketua Program Studi Fisioterapi dan Profesi Fisioterapi Fakultas Kedokteran Universitas Udayana; (c) Peneliti memberikan penjelasan kepada sampel; (d) Populasi mengisi blangko informed consent.

Tahap pelaksanaa: Menetapkan sampel kelompok yang telah memenuhi kreteria inklusi dan eksklusi; (b) sebelum dilakukan pengukuran postur pelvic terlebih dahulu seluruh sample melakukan pemanasan (warming up) di bawah instruksi dari therapist di mana dilakukan 10 kali back stretching yang terdiri dari fleksi, ekstensi dan rotasi serta 5 menit berjalan di sekitar ruangan; (c) Melakukan pengukuran:

1) Muscle Strength Test

a. Abdominal muscles: Isometric abdominal test digunakan untuk mengukur kekuatan dari abdominal muscles.

Position-Sample adalah supine dengan hip $45^{\circ}$ dan lutut $90^{\circ}$.

Test- Sample diminta untuk melakukan fleksi trunk dan menahannya.

Grading dari test ini adalah:

Normal (5) = tangan sample di belakang leher, sampai scapula terangkat dan tahan selama 2030 detik.

Good (4) = tangan sample menyilang pada dada, sampai scapula terangkat dan tahan selama 15-20 detik.

Cukup (3) = Tangan sample lurus, sampai scapula terangkat dan tahan 10-15 detik.

Kurang baik (2)= Tangan pasien lurus kearah lutut sampai scapula tengkat dan tahan 1-10 detik.

Buruk $(1)=$ tidak bisa mengangkat kepala dari posisi tidur.

b. Gluteal muscles:

Position: sample berada dalam posisi pronasi dengan hip lurus dan knee fleksi $90^{\circ}$

Test: Sample diminta untuk ekstensi hip dengan tetap mempertahankan posisi fleksi knee.

Grading dari test ini adalah:

Normal (5) = Dapat melakukan ekstensi hip dan 
dapat mempertahankan posisinya melawan gaya maksimal.

Good (4) = Dapat melakukan ekstensi hip dan dapat mempertahankan posisinya melawan gaya tahanan berat ringan.

Cukup (3) = Dapat melakukan ekstensi hip dan dapat mempertahankan posisinya tanpa tahanan.

Kurang baik (2) = Dapat melakukan ekstensi hip pada full ROM pada posisi side lying.

Buruk (1) = Sulit untuk melakukan kontraksi pada gluteus maximus.

\section{2) Thomas Test}

Melakukan pengukuran panjang dari Iliopsoas muscle dengan modified thomast test dengan Universal Goniometer. Panjang dari spinal extensor muscle dengan menggunakan mid line. Strength dari abdominal muscle dan bilateral gluteus maximus muscle di ukur sesuai dengan MRC grading pada manual muscle testing. Dan semua proses dari pengukuran dilakukan oleh sarjana fisioterapi ${ }^{7,8}$.

\section{F. Analisis Data}

Analisis data menggunakan SPSS versi 23.

1. Statistik deskirptif digunakan untuk:

a. Mengetahui gambaran umum dari sample (umur, tinggi, berat badan \& BMI).

b. Penentuan frekuensi dari pelvic cross syndrome pada subjek laki-laki dan perempuan.

c. Statistik deskirptif juga digunaka untuk mengetahui gambaran dari spinal extensors dan iliopsoas tightness, abdominals dan gluteus maximus weakness pada subjek laki-laki dan perempuan.

2. Chi- square test telah dilakukan untuk menentukan perbedaan dari strength gluteus dan abdominal muscle, adanya perbedaan fleksibilitas dan prevalensi angka kejadian LBP pada lower cross syndrome pada laki-laki dan perempuan.

\section{HASIL PENELITIAN}

\section{Deskripsi Karakteristik Subjek Penelitian}

Tabel 5.1

Distribusi Data Sampel

\begin{tabular}{llc}
\hline Karakteristik & & Nilai p \\
\hline Jenis Kelamin (\%) & & \\
Laki-Laki & 60 & 1,00 \\
$\begin{array}{l}\text { Perempuan } \\
\text { Umur (tahun) }\end{array}$ & 40 & \\
Mean \pm SD & & \\
\hline
\end{tabular}

2. Chi- Square Perbandingan Abdominal dan Gluteus Muscle Test

Tabel 5.2 Hasil Abdominal dan Gluteus

\begin{tabular}{|l|l|l|l|l|}
\multicolumn{5}{|c}{ Muscle Test } \\
\hline & $\begin{array}{l}\text { Wanita } \\
(\mathrm{n}=120)\end{array}$ & $\begin{array}{l}\text { Pria } \\
(\mathrm{n}=80)\end{array}$ & $\begin{array}{l}\text { Total } \\
(\mathrm{n}=200)\end{array}$ & $\begin{array}{l}\mathrm{p}- \\
\text { valu } \\
\mathrm{e}\end{array}$ \\
\hline Weak & $\begin{array}{l}82 \\
(69,17 \%)\end{array}$ & $\begin{array}{l}21 \\
(26,25 \%)\end{array}$ & 113 & $\begin{array}{l}0,00 \\
1\end{array}$ \\
\hline Good & $\begin{array}{l}38 \\
(30,83 \%)\end{array}$ & $\begin{array}{l}59 \\
(73,75 \%)\end{array}$ & 87 & \\
\hline
\end{tabular}

Berdasarkan tabel ChiSquare di atas hasil pengukuran abdominal test didapatkan hasil nilai $\mathrm{p}=0,001$ yang menunjukan adanya pebedaan jumah kekuatan kekuatan otot antar kelompok berjenis kelamin pria dan wanita yang signifikan, di mana pada wanita terdapat $69,17 \%$ memiliki kelemahan otot dibandingkan laki-laki 26,25\% pada 
total jumlah kelompok masingmasing.

\section{Chi- Square Perbandingan Fleksibilitas muscle}

Tabel 5.3 Hasil Pengukuran Fleksibilitas

\begin{tabular}{|l|l|l|l|l|}
\multicolumn{5}{|c}{ Muscle } \\
\hline & $\begin{array}{l}\text { Wanita } \\
(\mathrm{n}=120)\end{array}$ & $\begin{array}{l}\text { Pria } \\
(\mathrm{n}=80)\end{array}$ & $\begin{array}{l}\text { Total } \\
(\mathrm{n}=200 \\
)\end{array}$ & $\begin{array}{l}\mathrm{p}- \\
\text { valu } \\
\mathrm{e}\end{array}$ \\
\hline Tight & $\begin{array}{l}54 \\
(65.06 \%)\end{array}$ & $\begin{array}{l}57 \\
(48.72 \%)\end{array}$ & 91 & $\begin{array}{l}0,0 \\
21\end{array}$ \\
\cline { 1 - 3 } $\begin{array}{l}\text { Norm } \\
\text { al }\end{array}$ & $\begin{array}{l}29 \\
(34.94 \%)\end{array}$ & $\begin{array}{l}60 \\
(51.28 \%)\end{array}$ & 89 & \\
\hline
\end{tabular}

Dari tabel Chi-square di atas diperoleh perbedaan pada fleksibilitas muscle laki-laki dan wanita di mana diperoleh nilai $\mathrm{p}=0,021$ yang artinya terdapat perbedaan signifikan

\section{Chi-Square Prevalensi Low Back Pain dengan Lower Cross Syndrome pada Laki-Laki dan Perempuan dengan Oswestry Disability Index (ODI)}

Tabel 5.3

Prevalensi LBP pada LCS Laki-Laki dan Perempuan

\begin{tabular}{|l|l|l|l|l|}
\hline & $\begin{array}{l}\text { Wanita } \\
(\mathrm{n}=120)\end{array}$ & $\begin{array}{l}\text { Pria } \\
(\mathrm{n}=80)\end{array}$ & $\begin{array}{l}\text { Total } \\
(\mathrm{n}=200)\end{array}$ & $\begin{array}{l}\mathrm{p} \text { - } \\
\text { value }\end{array}$ \\
\hline $\begin{array}{l}\text { Affect } \\
\text { ed }\end{array}$ & $\begin{array}{l}83 \\
(69,16 \%)\end{array}$ & $\begin{array}{l}14 \\
(18,75 \%)\end{array}$ & 97 & 0,001 \\
\cline { 1 - 3 } Good & $\begin{array}{l}37 \\
(30,84 \%)\end{array}$ & $\begin{array}{l}66 \\
(81,25 \%)\end{array}$ & 103 & \\
\hline
\end{tabular}

Berdasarkan tabel di atas hasil pengukuran dari lower cross syndrome didapatkan hasil yang menunjukan adanya pebedaan jumah prevalensi antar kelompok dengan sample berjenis kelamin perempuan adalah 83 orang dari total 120 sample $(69,16 \%)$ lebih banyak mengalami pelvic cross syndrome dibandingkan laki-laki yaitu 14 orang dari 80 sample $(18,75 \%)$. Pada tabel juga didapatkan nilai $\mathrm{p}=0,001$ di mana artinya adalah terdapat hubungan antara Low Back Pain denga Lower Cross Syndrome.

\section{PEMBAHASAN}

\section{Hubungan Pelvic Cross Syndrome dengan LBP}

Salah satu dari dari faktor resiko yang penting dalam kejadian LBP pada kelompok usia remaja adalah adanya muscle imbalance. Pelvic cross syndrome merupakan suatu kejadian muscle imbalance di mana terjadi tightness dari hip flexors, lower back muscles dan weakness dari abdominals, gluteus maximus muscle; sehingga akan mengubah dari distribusi dan penyebaran gaya biomekanik pada regio lower back yang dapat menimbulkan keluhan chronic low back pain ${ }^{1,9}$.

Beberapa penelitian penting dilakukan di dunia guna mengantisipasi dan menganalisis keluhan low back pain, penelitian yang dilakukan oleh Janda menjelaskan konsep pelvic cross syndrome merupakan salah satu faktor penting yang mempengaruhi prevalensi angka kejadian low back pain ${ }^{10,11}$.

Janda's Pelvic Cross Syndrome atau disebut juga "lower cross syndrome" sudah sering digunakan sebagai assessment, rehabilitation dan corrective exercise strategis dalam upaya management muscle imbalance pada daerah lower vertebra dan lower extremities. Karakteristik dari pelvic cross syndrome ditandai adanya imbalance muscle torque pada anterior dan posterior pelvic muscle (Cross Pattern Line), di mana terjadi pemendekan dan tightness pada otot- 
otot flexor hip pada sisi anterior dan penurunan serta kelemahan dari gluteal dan abdominal muscle pada sisi posterior ${ }^{12}$.

$$
\text { Adanya imbalance muscle }
$$

torque dan perubahan sagital lumbopelvic posturomovement pada pelvic cross syndrome mengakibatkan adanya perubahan dari postur pelvic menjadi forward tilt dan meningkatkan kurva lodrosis lumbal. Kondisi otot hamstring dan gluteal pada keluhan ini seringkali ditemukan mengalami kekakuan (tightness) sebagai upaya mekanisme kompensasi tubuh mengurangi pelvic tilt. Dari pemeriksaan juga ditemukan over-activity dan tightness pada erector spine dan penurunan dari kekuatan gluteal muscle sehingga akan mengganggu hip exstension pattern yang merupakan aspek fundamental pada pola jalan manusia $^{13}$.

Muscle tightness tersebut merupakan hasil dari peningkatan tension dari mekanisme aktif atau pasif pada normal populasi. Secara aktif suatu otot dapat terjadi pemendekan oleh karena spasm atau kontraksi dan secara pasif akan memendek dari adaptasi secara postural. Bagaimanapun juga adanya tightness serta penurunan limits range of motion dapat menimbulkan muscle imbalance. Pada usia pertumbuhan jika soft tissue seperti muscle dan ligament tidak bisa mengikuti pertumbuhan dari tulang sehingga mengakibatkan muscle imbalance dan penurunan fleksibilitas pada kelompok usia muda ${ }^{14,15}$.

Ashmen et al. (1996) dalam penelitiannya telah memaparkan adanya pemendekan dan penurunan dari iliopsoas muscle merupakan factor mekanik yang sangat berpengaruh pada kejadian LBP karena adaya tightness pada iliopsoas muscle akan menyebabkan meningkatnya lumbar lordosis dan kelemahan dari otot ini akan mengakibatkan penurunan dari lordosis lumbar yang merupakan salah satu postur resiko $\mathrm{LBP}^{16}$.

Hasil yang diperoleh pada penelitian ini sesuai dengan teori Sherrington's law dari recriprocal innervation dimana suatu otot yang tight akan menyebabkan reflex inhibition atau perlemahan dari otot sisi sebrang tubuh (antagonis) ${ }^{17}$. Teori yang sama juga dikemukakan oleh Kendall yang percaya back extensor muscle akan menjadi tight yang diakibatkan oleh abdominal muscle weakness dari postur duduk jangka waktu lama ${ }^{18}$.

Menurut penelitian yang telah dilakukan oleh Janda pada tahun 1978 dengan subjek sample yang sering melakukan kesalahan postur pada saat duduk lama setelah dilakukan observasi ditemukan efek jangka panjang dari static postur saat duduk di kursi sepanjang hari akan menyebabkan pemendekan dari hip flexor sehingga menjadi tight. Hal tersebut secara otomatis direspon oleh otak dengan menghentikan atau memperlemah gluteus muscle yang berada di sisi berlawanan ${ }^{12}$,

Diharapkan dari pengetahuan mengenai adanya imbalance muscle tightness dan penurunan fleksibilitas yang merupakan gejala klinis dari Lower Cross syndrome akan dapat mengurangi angka kejadia low back pain ke depannya. Preventif exercise juga dapat dilakukan untuk mencegah inbalance muscle dan dapat mengurangi gangguan fungsioal yang ditimbulkan ${ }^{18}$. 


\section{SIMPULAN}

Terdapat hubungan yang signifikan antara Low Back Pain dengan Lower Cross Syndrome

\section{DAFTAR PUSTAKA}

1. Alter MJ.2002. Science of Flexibility. Champaign, IL. Human Kinetics.

2. Key, J., Clift, A., Condie, F., Harley, 2008a. A model of movement dysfunction provides a classification system guiding diagnosis and therapeutic care in spinal pain and related musculoskeletal syndromes: a paradigm shift e part 1. J. Bodyw. Mov. Ther.

3. Janda, V. 1993. Muscle strength in relation to muscle length, pain, and muscle imbalance. In Muscle strength. Vol. 8 of International perspectives in physical therapy, ed. K. Harms-Ringdahl, 83-91. Edinburgh:Churchill Livingstone.

4. Justyna Drzal-Grabiec, Slawomir Snela, Justyna Rykala, Justyna Podgorska, Maciej Rachwal. 2015. Effect of the sitting position on the body posture of children aged 11 to 13 years. Work.;51(4):855-862

5. Dhanani S, Dr. Tarpan Shah. 2014. A survey on prevalence of lower crossed syndrome in young females.IJPSH.;1:2249-5738

6. Kisner C .Colby L A. 2007.Therapeutic exercise.5th ed.JAYPEE..pg 240.

7. FreseE.BrownM.NortonBJ.Clinic al reliability of manual muscle testing.middletrapezious and gluteus mediusmuscles.Europe PMC.; 67(7):1072-1076.
8. Kendall, F.P., E.K. McCreary, and P.G. Provance. 1993.Muscles. Testing and function. 4th ed. Baltimore: Williams \& Wilkins.

9. Janda V. 1987. Muscles and motor control in low back pain: Assessment and management. In Physical therapy of the low back. New York: Churchill Livingstone; 1987.253- 78

10. Burton AK, Clarke RD, McClune TD, Tillotson KM. 1996. The natural history of low back pain in adolescents. Spine 21:2323-2328

11. Janda, V. 1986b. Some aspects of extracranial causes of facial pain. J Pros the t Dent 56(4): 484-7.

12. Luyerink. VrugtA. 2000.The Contribution of Bodily Posture to Gender Stereotypical Impressions. Social Behavior and Personality.;28(1):91-104.

13. David G Borstein, Sam W Wiesel, Scott D Boden. 1989 . Low back pain: medical diagnosis and comprehension .management: -2 nd ed. pg. 22, 23, 59

14. Janssen J.HeymsfieldSB. WangZM.RossR. 2014. Skeletal muscle mass and distribution in 468 men and women aged 1888 years.JAppl Physiol.; 116(10) $: 1342$.

15. Ashmen KJ, Swanik CB, Lephart SM. 1996. Strength and flexibility characteristics of athletes with chronic low back pain. J Sport Rehabil;5:275-286.

16. Janda,V.1978.Muscles, central nervous regulation and back problems. In Neurobiological mechanismsin manipulative therapy, ed. I.M. Korr, 27-New York: Plenum Press.

17. Sherrington, C S . 1907. On reciprocal innervation of 
antagonistic muscles. Proc R SocLond B BiolSci79B: 337.7

18. Kendall, F.P., E.K. McCreary, and P.G. Provance.

1993.Muscles. Testing and function. 4th ed. Baltimore: Williams \& Wilkins. 